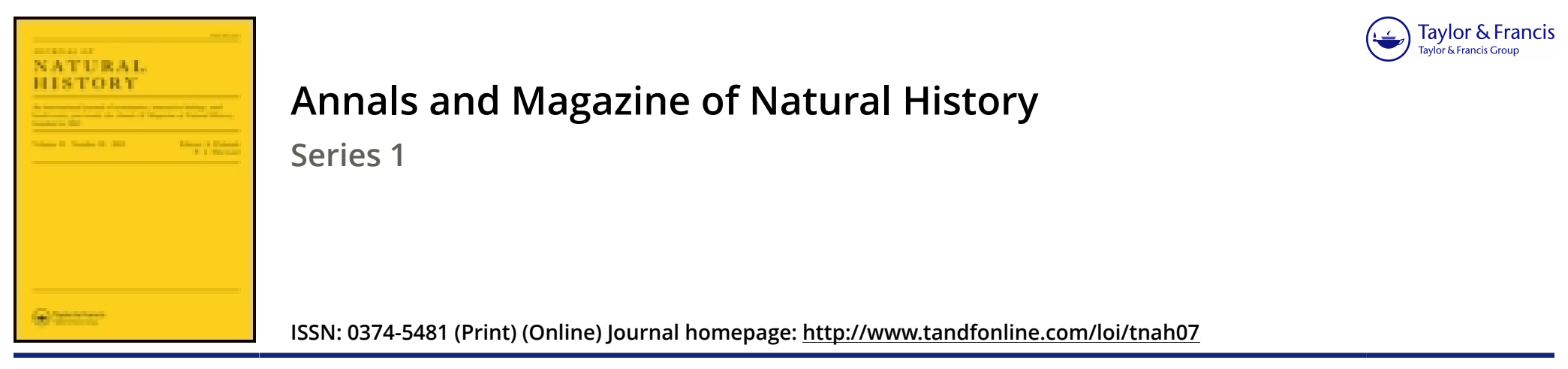

\title{
VII.-Description of a new species of Melanogaster
}

\section{C.E. Broome Esq.}

To cite this article: C.E. Broome Esq. (1845) VII.-Description of a new species of Melanogaster, Annals and Magazine of Natural History, 15:95, 41-42, DOI: $10.1080 / 037454809495246$

To link to this article: http://dx.doi.org/10.1080/037454809495246

$$
\text { 曲 Published online: } 17 \text { Dec } 2009 .
$$

Submit your article to this journal ๘

\footnotetext{
Q View related articles $\longleftarrow$
} 
nato, elytris ochracescenti-viridibus, corpore subtus pedibusque metallico-viridibus, rubro-tinctis. Iong. $\sigma^{-}$unc. 1 , lin. 4 ; $q$ unc. 1, lin. 3.

Hab. Abyssinia.

$\delta q$ in Mus. "Hon. E. Ind. Co."; $q$ in Mus. Brit. T. Horsfield, M.D. Hoc insectum in honorem Thomæ Horsfield, M.D., Faunæ Floræque Javanicæ insularumque orientalium aliarum scrutatoris celeberrimi, nominavi.

Male.-Head above brown, on under side in some lights of a brilliant deep blue or bluish green; the clypeus excavated on under side at base of fork. Thorax and scutellum above of a rich deep rusty brown colour, the former narrowly margined with bright green, growing fainter where the thorax joins the scutellum; sides and under side metallic green. Elytra of a faded yellowish green, the surface dimpled; on the suture and near the scutellum lively green.

Female.-Head and thorax rich rusty brown, posterior half of the latter rather paler. Elytra plainer than in male and of a more lively green with the suture golden; lateral edge of elytra as in the male, with many light-coloured cilia which extend to the apex ; the shoulders and a spot near the apex brown; under side and legs of a bright coppery red, segments slightly margined with green ; tarsi of all the legs and tibiæ of fore-legs brownish.

VII.-Description of a new species of Melanogaster. By C. E. Broome, Esq.

Sir, To Richard Taylor, Esq.

MAY I be permitted through the medium of your Journal to dedicate to my friend the Rev. M. J. Berkeley, to whose unwearied researches mycology is most deeply indebted, a pretty, new species of Melanogaster which I have lately met with in this neighbourhood? The characters are as follows :-

Melanogaster Berkeleianus, n. s. Parvus, globosus, longe radicatus; peridio sericeo albo, tactu gilvo fusco, intus pallide flavo; sporis minutis oblongo-ellipticis hyalinis albis, binucleatis.

The single specimen hitherto found was about the size of a pea, furnished with a long white root, which, as well as the silky white globose peridium, changed on the touch, or exposure to the air, to a pink-brown; the interior is of a delicate pale yellow, which is permanent; the texture of the walls of the cells is loosely cellular; spores elliptic-oblong, hyaline, containing two or sometimes three globose nuclei. In the form and colour of the spores this species very much resembles Octaviana aphrodisiaea of Mon- 
tagne. Some of the spores appeared to be uniseptate, but this might arise from ocular deception. It grew in a loose soil in a wood composed of hazel, beech and firs, in October last.

I am, Sir, your obedient servant,

Wraxall, near Bristol,

C. E. Broome.

23rd December, 1844.

VIII.-On the Laws which regulate the Geographical Distribution of Littoral Mollusca. By M. Alcide d'OrbignY*.

THE author in the first place urges the importance of investigations on the geographical distribution of the coast mollusca, as applied to general palæontology. It is, in fact, in the laws which at present regulate the geographical distribution of creatures that we must logically seek by comparison for light upon the successive animalization on the surface of the globe at all geological periods, in order to substitute well-ascertained facts for doubtful theories.

The author selected, as the theatre of his observations, South America, where he resided for eight years. Being at first of opinion, à priori, that the configuration of that continent, with relation to its latitude, the abrupt or very gradual slopes of its coasts, and the general currents which wash them, must have an immense influence upon this question, he points out particularly the characters which distinguish that part of the world, assisted, for these currents, by M. Duperrey's important map of the movement of the waters, without which he would have been unable to explain the anomaly of some facts. He presents in a table the name and habitat of 362 species of littoral mollusca, which, divided according as they belong to either of the two oceans, give 156 species peculiar to the Atlantic ocean, 205 species peculiar to the Pacific, and a single species common to both seas.

He examines separately the local faunas of the Atlantic and of the Pacific. In the first he finds that the Falkland islands have a peculiar fauna, that the fauna of the temperate regions is more numerous than that of the hot regions, and that each of these regions possesses from four to six times more peculiar than common species. The Pacific presented identical results relatively to the number of species peculiar and common to the hot and temperate regions; but the currents have there more influence on the partition of the species and on the separation of the local faunas where their action ceases.

His observations of the influence due to the orographic configuration of the coasts upon the zoological composition of the re-

*Frow the 'Comptes Rendus,' Nov, 18 th, being an abstract by the author. 